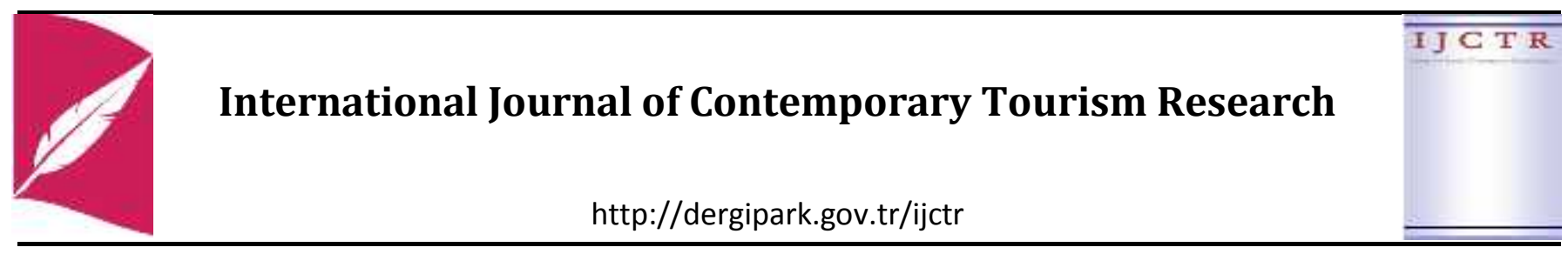

DEST NASYON MARKALAŞMASINDA FEST VAL TUR ZM N N ROLÜ: ALAÇATI OT FEST VAL ÜZER NE B R ÇALIŞMA

\author{
Melih ÇOBAN*, Seda SÜER ${ }^{* *}$
}

ÖZET

Etkinliklerin son 15-20 yıldır hızlı gelişimi destinasyonların hem ekonomik hem de sosyal olarak gelişmesine katkıda bulunmuştur. Bu gelişim gelecekte de devam edecektir. Bunun nedeni, etkinliklerin çeşidinin ve boyutunun her yıl gelişerek devam etmesidir. Bu çalışmanın konusu olan festival turizmi etkinlik turizminin en önemli yapı taşlarından bir tanesidir. Turizm ve etkinlik kavramlarının kesiştiği bir noktada bulunan festival turizmi, diğer destinasyonlara göre rekabet avantajının sağlaması, turizm sezonunu uzatması ve mevsimlere yayması gibi üstünlükleri ile turizme olan ilgiyi arttırmaktadır. Festivaller, gerçekleştirildiği destinasyondaki turist sayısını arttırmakta, destinasyonun tanıtımında ve bir marka olmasında katkıda bulunmakta böylece destinasyon için değer yaratmaktadır. Bu çalışmada Alaçatı Ot Festivali’nin, Alaçatı destinasyonunun bir marka olmasındaki etkisi incelenmiş, bölgede hizmet veren işletmelerle görüşülmüş ve algıları ölçülmeye çalışılmıştır. Alaçatı Ot Festivali'ne ilişkin algılar değerlendirilerek festivalin daha etkin gerçekleştirilmesi için bazı önerilerde bulunulmuştur.

Anahtar Kelimeler: Festival Turizmi, Marka, Destinasyon Markalaşması, Alaçatı Ot Festivali

JEL Sınıflama Kodları: L83, M31, M39, Z19

\title{
THE ROLE OF THE FESTIVAL TOURISM IN THE DESTINATION BRANDING: A STUDY ON ALACATI HERB FESTIVAL
}

\begin{abstract}
The rapid development of activities over the last 15-20 years has contributed to the development of destinations both economically and socially. This development will continue in the future. The reason for this is that the style and size of the events continue to improve each year. The festival tourism which is the basis of the study is also one of the most important parts of the event tourism. The festival tourism which is a common point of tourism and activity concepts, increases the interest of tourism by providing competitive advantage compared to other destinations, extending tourism season and spreading it in tourism seasons. Festivals contribute to increasing the number of tourists in the destination, promoting destinations and becoming a brand, and creating value for the destination. For this purpose, the effect of Alaçatı Herb Festival on being a brand of Alaçatı Destination was investigated and the operators working in the region were interviewed and tried to measure their perceptions. Some suggestions are proposed to contribute the festival to be more effective by evaluating the perceptions of the Alaçatı Herb Festival.
\end{abstract}

Key Words: Festival Tourism, Destination, Brand, Destination Branding, Alaçatı Herb Festival JEL Classification Code: L83, M31, M39, Z19

\footnotetext{
* Bilim Uzmanı, zmir Kâtip Çelebi Üniversitesi, Sosyal Bilimler Enstitüsü, Turizm şletmeciliği Anabilim Dalı, melihcoban90@gmail.com

*** Dr. Öğr. Ü., zmir Kâtip Çelebi Üniversitesi, Turizm Fakültesi, Turizm şletmeciliği Bölümü, seda.suer@ikc.edu.tr

doi: $10.30625 / i j c t r .424439$
} 


\section{G R Ş}

Festivaller, çeşitli nedenlerle belirli dönemlerde gerçekleştirilen toplumsal kutlamalar olarak ifade edilmektedir. çerikleri, amaçları, zamanları, mekânları, organizasyon şekilleri gibi unsurların farklılıklarından dolayı festival kavramı üzerine tam bir tanım verilememektedir. Ayrica, araştırmacıların düzenlenen festivallere toplumsal, kültürel ve ekonomik olmak üzere farklı açılardan bakması ortaya çıkan tanımlarda ifade birliğinin oluşturulamamasına neden olmuştur. Festivaller, bireysel ve toplumsal kimliğin bir parçası olmakla beraber toplum, kültürel çevre ve bireyler arasında bağları güçlendirmeyi sağlar (Golblatt, 1997:7). Festivaller, toplumun sosyal normlarının ve değerlerinin bir ifadesi olarak görülen toplumsal faaliyetlerdir (Chacko ve Shaffer, 1993). Festivaller, insanlar ve toplumlar arasinda ekonomik, sanatsal, kültürel ve sosyal açıdan bir yakınlaşma ve tanıtım sağlamak amacıyla düzenlenen etkinliklerdir (Bilgili vd, 2012: 118). Festivaller, bir ülkenin ya da ülkede yaşayan bir topluluğun tarihini, dünya görüşünü, sosyal ve kültürel kimliğini sergileyen temalı kutlamalardır (Miller, 2004: 5). Festivaller, toplumun yaşam biçiminin değerli yönlerini kutlayan ve kısa süreliğine sahneye konmak için tasarlanan, belirli bir temayı içeren halk olaylarıdır (Dinmock ve Tiyce, 2001: 375).

Festivaller üzerine çalışmaları olan Falassi (1987:3-4) ise, festivalleri aşağıdaki gibi özetlemiştir. Festivaller;

- Kutsal veya kültürel, özel gelenek /göreneklerle belirginleşmiş kutlamalar,

- Belirli bir insan ya da olayın veya önemli bir ürünün hasatıyla ilgili yıllık kutlamalar,

- Genellikle tek bir sanatçı veya sanat dalına adanmış bir dizi güzel sanatlar çalışmasının yapılmasını içeren kültürel etkinlikler,

- Fuar ve panayırlar,

- Genel, herkese açık şenlik, ziyafet ve eğlencelerdir (Karagöz, 2006: 23).

Festival tanımı diğer etkinlik tanımları ile karşılaştırıldığında halkı kapsayan bir etkinlik olduğu görülmektedir. Aslında birçok festival genellikle toplumun sosyal normlarının ve değerlerinin bir ifadesi olarak görülen küçük toplumsal etkinler olarak ortaya çıkmıştır. Genel anlamda tipik festivallerin bir toplum tarafindan yaratılması ve o toplumu yansittlğ 1 bilindiğine göre; bir festival halk temalı kutlamalar olarak gerçekleşen özel bir etkinlik olarak tanımlanabilir. $\mathrm{Bu}$ tanımın odak noktası toplumsal temelli veya toplum tarafından sahiplenilmiş olmasıdır. Karagöz'e göre bir festivalin bir toplumda neden düzenlendiğinin muhtemel nedenleri şöyledir (Karagöz, 2006: 25):

- Toplumun heyecanını ve gururunu arttırmak,

- Toplumun neden eşsiz ve özel olduğunu göstermek,

- Toplumun kültürel becerilerini ve yeteneklerini keşfetmeleri ve geliştirmeleri için firsat sağlamak,

- Bölge halkının tiyatro, müzik, sanat ve değer yaratıcı alanlarda yeni faaliyetlerle uğraşması için firsatlar sağlamak,

- Özel projeler için gelir sağlamak,

- Bir insanı, tarihi ya da önemli bir olay1 onurlandırmaktır.

Festival turizmi ile genelde kastedilen bir festival dönemi boyunca dışarıdan insanların festival bölgesini ziyaret etmesi olayıdır. Diğer tanımlarda festival turizmi, sınırlı ve sürekli etkinliklerle bir turizm destinasyonunun farkındalığını, çekiciliğini ve kârlılığını arttırarak geliştirilmesini içermektedir (Visser 2005: 156' dan aktaran Kömürcü 2013: 29). Günümüzde Berlin Film Festivali, Cannes Film Festivali, Uluslararası Antalya Altın Portakal Film Festivali gibi festivaller düzenlendikleri ilin ismini taşıyarak o ili marka haline getirmiştir. Kültür ve Turizm Bakanlığı'nın verilerinden derlenen bilgiye göre, her y1l yurt genelinde festival, şenlik özel gün, özel hafta, dini ve milli bayram adı altında yaklaşık bin 300 etkinlik gerçekleştirilmektedir. Sinema, tiyatro, müzik, yiyecek, dans, spor ve karikatür gibi farklı konularda düzenlenen etkinlikler, ağırlıklı olarak kültürel yaşama canlılık katmayı ve illeri markalaştırmayı amaçlamaktadır. Festivaller gibi özel olaylar, modern turizmin imajını oluştururken kullanılan en önemli araçlardan biri olarak görülmektedir. Festivaller turizm pazarında talebi arttırmak, turistin ilgisini çekmek, destinasyonun imajını geliştirmek ve markalaşmak için bir halkla ilişkiler aracı olarak kullanılmaktadır. Günümüzde festivaller bir destinasyonun doğal ve fiziksel özelliklerinin önüne geçmeye başlamıştır (Ekin, 2011: 41,42). 
Festivallerin destinasyonun tanitılmasında kullanılan etkili bir yöntem olduğu bilindiğine göre bu durum turistik talep artışını sağlayacaktır. Festival dolayisı ile destinasyona gelen turist, festival boyunca konaklayacak ve destinasyondan memnun kalması durumunda daha sonraki turistik faaliyetlerinde tekrar aynı destinasyonu tercih edebilecektir. Festivallerin bir başka etkisi ise turistin konaklama süresini uzatmasıdır. Turizm potansiyeline bağlı olarak geliştirilen festivaller temel çekiciliklere yardımcı olabilmelerinin yanı sıra zaman içerisinde destinasyon ile bütünleşerek marka haline gelebilmektedirler. Tipkı yukarıda verilen Rio Karnavalı ve Cannes Film Festivali gibi. Bunların yanında festivallerin imaj yaratıcı ve destekleyici işlevi de olabilmektedir. Oluşturulmak istenilen destinasyon imaji ile o destinasyonda yapılan festival imaj aynı ise hedeflenen imaj pekiştirilmiş olur (Çelik, 2009: 95, Ekin, 2011: 4).

\section{DEST NASYON MARKALAŞMASI VE FEST VALLER}

Birçok endüstride olduğu gibi turizm endüstrisinde de müşteri odaklı pazar anlayışına önem verilmiştir. $\mathrm{Bu}$ sebeple destinasyonların sahip olduğu kaynaklar ve özellikler, gelen turistlerin ihtiyaçlarına en iyi şekilde cevap verebilecek nitelikte düzenlenmektedir. $\mathrm{Bu}$ düzenlemeler, doğal olarak üst düzey rekabet ortamının oluşmasına sebep olmaktadır. Bu nedenle ülkeler, destinasyon markalaşması gibi son zamanlarda öne çıkan rekabet unsurunu kullanmaktadır (Kaya, 2014: 44).

Çok hızlı bir şekilde artan rekabet koşulları içerisinde destinasyonlar farklılıklarını ortaya koyup, kendilerine kimlik kazandıracak markalaşma faaliyetlerinde bulunması kesinlikle şart olmuştur. $\mathrm{Bu}$ bağlamda destinasyon markalaşmasını Özkul ve Demirer (2012: 159) şu şekilde tanımlamıştır: "Yöreye özgü ve tutarlı unsurlar, özellikler karması oluşturarak, ilgili destinasyonu diğerlerinden farklı kılan ve ona kimlik kazandıran bir yapı ile olumlu bir imaj inşa edilmesidir."'

Etkili bir destinasyon markalaşması oluşturmak için, bölgenin geleceği için net bir vizyonun olması, aynı zamanda markanın gelişmesi ile uyumlu bir strateji, bununla birlikte etkili politika uygulamaları ve etkin bir iletişim gereklidir. Destinasyon bölgelerinde etkili bir marka yaratmak için cevap verilmesi gereken üç tane önemli soru bulunmaktadır. Bunlar (Kaya, 2014: 45):

- Destinasyonun diğer bölgelere göre nasıl bir farklılığa sahip olduğu,

- Rakiplerinden onları ayıran hizmetlerin ve niteliklerin ne olduğu,

- Paydaşlara önerilen öncelikli değerlerin ne olduğu önemli sorulardır.

Özdemir'e (2007: 138) göre başarılı bir destinasyon markasinda bulunması gereken özellikleri 11 maddeden oluşmaktadır: Bunlar; 1. Güçlü konumlama yapmak, 2. Baştan satın alım yapmak, 3. Etkileyenleri etkilemek, 4.Yerel şampiyonlar yaratmak, 5. Bir marka, yüzlerce ortak ve tek ses gibi hareket etmek, 6.Bir reklam kampanyasından daha fazla bir şeyi ifade etmek, 7. Toplu marka, 8. Süreklilik ve odaklanma sağlamak, 9. Toplam destinasyon deneyimini geliştirmek, 10. Uzun süreli bağlllık kurmak, 11. Objektif bir bakışa sahip olmaktır.

Destinasyon markalaşmasının amacı, destinasyona gelen ya da gelmesi istenen turistler ile destinasyon arasında duygusal bir bağın kurulmasını sağlamaktır. Destinasyonun kendi markası ile pazarlamanın daha verimli sonuçlar verebileceği düşünülmektedir. Destinasyon markalaşmasını oluşturan en temel unsur tüketici ve destinasyon bölgesidir.

Destinasyon markalaşmasının faydalan şöyle siralanabilir (Pekyaman, 2008: 47):

- Markalar, ürünleri farklılaştırmanın yanında insanların duygularını uyandırmakta ve bu duyguları davranışa dönüştürmektedir. Güçlü ülke markası hem turistleri hem de yatırımları ülkeye çekmektedir.

- Marka, rekabetçi ortamda bir destinasyonu farklılaştırmakta ve özel kılmaktadır.

- Turistin, destinasyonu tanımasını ve benzer destinasyonlardan ayırt etmesini sağlar.

- Turizmin özelliği sebebi ile ürünün satın alınmadan önce denenmesinin getireceği riskleri azaltır.

- Destinasyonun markalaşması, destinasyonu simgeleyen ürünlerin de markalaşması çabalarını kolaylaştırır.

- Destinasyonlara tekrarlı gelişlere neden olur. $\mathrm{Bu}$ durum, ziyaretçi ile arasında duygusal bağ kurmasını sağlar. 
- Destinasyonlar arasında fark yaratarak, destinasyonun tanınmasını sağlar.

- Turistlerin destinasyona karş1 güven duymasını sağlar ve böylece destinasyon seçim sürecini kolaylaştırır.

Festival turizmi, turizm pazarında hızla büyüyen bir sektör olup, turizm sezonunu uzatmak, turizmi çeşitlendirmek, turizm talebinin artmasını sağlamak, bölgeye yeni gelir kaynağı yaratmak, destinasyonların çekiciliğini ve farkındalığını arttırmak, destinasyona medyanın ilgisini çekmek, güçlü ve aktif imajlar oluşturarak kültürel temalar yaratarak destinasyonun markalaşmasına yardımcı olmaktadır. Festivallere gelen turistler, destinasyona yönelik izlenimlerini geliştirmekte ve böylece destinasyona yönelik farkındalıkları da artmaktadır. Turistler festivallerde bizzat yaşadıkları tecrübeler ve duygularla herhangi bir pazarlama programının ulaşmayı hedeflediği etkiden daha fazla etki birakabilme gücüne sahiptir (Akpınar, 2013: 17).

Destinasyonların markalaşması çalışmaları gerçekleştirilirken, tanıtım özelliğine sahip festivaller önemli bir yere sahiptir. Günümüzde Cannes Film Festivali, Rio Karnavalı, Antalya Altın Portakal Film Festivali gibi örnekler destinasyonların markalaşmasına önemli örneklerdendir (Doğanlı, 2006: 112). Dünya'da pek çok ülke yerel ve ulusal festivalleri sayesinde her y1l on binlerce turist çekmektedir. Tüm dünyada olduğu gibi ülkemizde de geleneksel özellikler taşıyan ve kültürel birtakım değerleri yaşatmak ve tanitmak için festivaller düzenlenmektedir. $\mathrm{Bu}$ sayede destinasyona medyanın ilgisi çekilerek, güçlü imajlar yaratılarak destinasyon markalaşmasına yardımcı olunmaktadır. Festivaller sayesinde sadece ekonomik yarar sağlamakla kalmayıp, destinasyonun farklı ülkelerden gelen turistler sayesinde uluslararası alanda tanitımı sağlanmaktadır.

\section{ARAŞTIRMANIN YÖNTEM}

Destinasyonların markalaşması, bulundukları bölgenin imajını olumlu şekilde arttırıcı bir etkiye sahiptir. Marka oluşturmanın önemli bir rekabet aracı olarak görülmesi turizm sektöründe farklı pazarlama anlayışlarının ön plana çıkmasını sağlamış, bir ülkenin tek destinasyon ve tek turistik ürün olarak pazarlanması terk edilerek, ülkelerin çeşitli bölgeleri turistik ürün kimlikleri ön plana çıkartılarak turistik tanıtım ve pazarlaması yapılmaktadır. $\quad \mathrm{Bu}$ çalışmada, Türkiye gibi turizmin çeşitli olabileceği ülkelerde, turizm sezonunun bütün yıla yayılmasını sağlamak amacıyla bir alternatif turizm çeşidi olarak festival ve etkinlik turizminin önemini ortaya koymak amaçlanmıştır. Turizm açısından önemli destinasyonlardan biri olan Alaçatı'nın marka haline gelme sürecinde düzenlenen Alaçatı $\mathrm{Ot}$ Festivali'nin destinasyonun markalaşmasına etkisi festival turizmi kapsamında incelenmiştir. $\mathrm{Bu}$ çalışmada ayrıca Alaçatı'nın bir destinasyon markası olarak algılanma düzeyinin tespit edilmesi amaçlanmıştır. Çalışmanın amacına yönelik hazırlanan görüşme formu "Alaçatı destinasyonun markalaşmasında Alaçatı Ot Festivalinin markalaşma sürecine etkisini ölçmek ve bölgeye olan katkısını arttırmak için neler yapılabilir?" ana temasından yola çıkarak aşağıdaki araştırma soruları geliştirilmiştir.

1. Alaçatı Ot Festivalinin düzenlenme sebebi sizce nedir?

2. Alaçatı Ot Festivalinin bölgeye gelen turist sayısının sizce arttırıcı bir özelliği var mıdır?

3. Alaçatı'ya gelen turistlerin sizce gelme nedenleri nelerdir?

4. Alaçatı Ot Festivalinin işletmeler açısından önemini açıklar mısınız?

5. Alaçatı Ot Festivalinin destinasyon markalaşmasında etkisini bölge açısından nasıl değerlendiriyorsunuz?

6. Festivalin bölgeye olan katkısını arttırmak için ne gibi önerilerde bulunabilirsiniz?

7. Festivalin ulusal ve uluslararasi tanınabilirliğini arttırmak için sizce neler yapilabilir?

$\mathrm{Bu}$ çalışmanın önemi, bir destinasyonun markalaşmasında festival turizmin rolünü o bölgenin paydaşlarının düşüncelerini derinlemesine incelenmesidir. Destinasyon markalaşma sürecinde festival turizminin destinasyona kattığı değeri ve marka olmasında festival turizminin önemini ortaya çıkarmak ve yerel halkın bu konudaki farkındalığını sağlamak bu çalışmanın önemini teşkil etmektedir.

Bu çalışmada "Alaçatı Ot Festivali" vaka olarak seçilip incelendiğinden kalitatif araştırma tekniklerinden kalitatif vaka analizi yöntemi uygulanmıştır. Yin (2002: 23)'e göre seçilen herhangi bir olguyu ya da durumu daha derinden 
irdelemek, katılımcıların görüşleri ya da bakış açılarını aralarındaki benzerlikler ya da farklılıklara göre konuyu yakından anlamak ve aktarmak vaka analizi olarak adlandırılmaktadır. $\mathrm{Bu}$ çalışmada kalitatif vaka analizi yönteminin uygulanmasının sebebi analiz yapılan vaka ile ilgili derinlemesine bilgiler sağlama adına en sık kullanılan yöntemlerden biri olmasıdır. Özellikle firmaları derinlemesine incelemek ya da örgütsel davranışları yakından anlamak için genellikle başvurulan ve kullanılan yöntemlerdendir (Ritchie ve Lewis, 2003: 66'dan aktaran Deniz ve Bedir; 2017:179). Kalitatif araştırmalar; gözlem, görüşme ve doküman analizi gibi nitel veri toplama yöntemlerinin kullanıldığı, algıların ve olayların doğal ortamda gerçekçi ve bütüncül bir biçimde ortaya konmasına yönelik nitel bir sürecin izlendiği araştırma olarak tanımlanır. Başka bir deyişle kalitatif araştırma, kuram oluşturmayı temel alan bir anlayışla sosyal olguları bağlı bulundukları çevre içerisinde araştırmayı ve anlamayı ön plana alan bir yaklaşımdır (Yıldırım ve Şimşek, 2000: 19'dan aktaran Altındağ, 2005: 2).

Stake (2005, 445-46)' göre üç çeşit vaka analizi yapılabilir. Bunlar, içkin vaka analizi, enstrümental vaka analizi, çoklu (kolektif) vaka çalışmalarıdır. $\mathrm{Bu}$ çalışmada tek bir vaka incelendiğinden, çoklu vaka ele alınmadığından ve karşılaştırma yapılmadığından vaka analizi çeşitlerinden olan 'içkin ve enstrümental vaka analizi'nin özellikleri bulunmaktadır. Ayrıca vaka analizi çalışmaları derinlemesine veri toplamak ve analiz edebilmek için genellikle 3 ya da 4 kadar az katılımcı ile gerçekleştirilir (Ritchie ve Lewis, 2003: 484'dan aktaran Deniz ve Bedir; 2017:179). $\mathrm{Bu}$ çalışmada da derinlemesine veri elde edebilmek amacıyla konuyla ilgili detaylı bilgi verebilecek az katılımcı ile çalışılmıştır. Ayrıca çalışmada, kalitatif vaka araştırma yöntemlerinden görüşme tekniği tercih edilmiştir. Görüşme tekniği, genel tanıma bakıldığı zaman araştırmacının katılımcılara kapalı uçludan açık uçluya kadar uzanan bir yelpazede sorular sorarak bilginin toplandığı ve görüssme yapılan katılımcının bakış açısının öğrenildiği bir yöntemdir. Görüşmenin amac1, bir bireyin iç dünyasına girmek ve onun bakış açısını anlamaktır. Araştırmanın ele aldığı konuya, görüşmenin yapıldığı kişi sayısına, soruların yapısına göre farklı gruplandırmalar ve isimlendirmeler yapılmaktadır. $\mathrm{Bu}$ farklı kategorilere ve ortak noktalara bakılarak genel olarak görüşme yöntemi üç başlık altında ele alınmaktadır (Seggie ve Bayyurt, 2015: 45-47).

- Yapılandırılmış Görüşme: Soruların ve sıralamaların kesin olduğu görüşme yöntemidir.

- Yarı Yapılandırılmış Görüşme: Araştırmacının ele alacağı konu başlıkları mevcuttur ve her katılımcıya yaklaşık olarak benzer sorular sorulur.

- Yapılandırılmamış Görüssme: Gündelik yaşantıdaki sohbete benzer ve katılımcının serbestçe görüşlerinin alındığı görüşme çeşididir.

Görüşme tekniği, bireysel veya birden fazla kişi ile yapılan görüşmeler olarak çeşitlenmektedir. Yapılan araştırma ve çalışmalarda üç görüşme çeşidinden bahsedilmiştir. Bunlar; bireysel görüşme, çoklu görüşme ve grup tartışması şeklindedir (Seggie ve Bayyurt 2015: 47). Bu çalışmada bireysel görüşme tekniğinin uygulanmasının sebebi tek bir kişi üzerine yoğunlaşabilmektir. Görüşme formunda bulunan sorular yapılandırılmış ve yarı yapılandırılmış olarak uygulanmasının sebebi araştırılan konuyu derinlemesine ele alabilmektir.

\section{Örneklem Seçimi Ve Veri Toplama Yöntemi}

Kalitatif vaka analizi uygulanarak yapılan bu çalışmada vaka olarak Alaçatı Ot Festivali seçilmiştir. Araştırmada kalitatif vaka analizi tekniğinin seçilmesinin nedeni, araştırmacının konuyu doğal çevrede incelemek istemesi, bütüncül bir yaklaşım yapabilme, algıların ortaya konması ve araştırma deseninin esnek olmasıdır. Çalışmada veri toplama amacıyla örneklem seçimi tesadüfi olmayan örnekleme yöntemlerinden biri olan kartopu örneklem tekniği kullanılmıştır. Kolayda örnekleme tekniği olarak ele alınan kartopu örneklem tekniğinin amac1, çalışma doğrultusunda kolaylıkla erişilebilen, hedeflenen ya da beklenen özgün karakteristikleri taşıyan kişileri belirlemeye ve seçmeye dayanmaktadır (Deniz ve Bedir, 2017: 179).

Diğer bir taraftan kalitatif çalışmalarda katılımcıların araştırmaya gönüllü katılımları araştırmanın geçerliliği ve güvenilirliği için önem teşkil etmektedir. Bu sebeple onaylı rıza ve gönüllü katılım doğrultusunda etik hususlar sağlanmaktadır (DeRoche ve DeRoche, 2010: 339). Ayrica çalışmada, kalitatif araştırma yöntemlerinde veri 
toplama amacıyla sıklıkla kullanılan yüzyüze, derinlemesine, yarı-yapılandırılmış görüşme yöntemi kullanılmıştır. Bu görüşmeler genellikle en az 1 saat sürecek şekilde ve katılımcının belirleyeceği bir yerde yapılır. Öte yandan sorulan sorular çok dar olmayan ancak odaklanmış, teoriden beslenen ancak katkı sunma ya da bir boşluğu doldurma adına potansiyel sunan, araştırmacıyı ilgilendiren, tam ve açık sorular olmalıdır (Keegan, 2009: 71-80; Ritchie ve Lewis, 2003: 36-48'dan aktaran Deniz ve Bedir; 2017:180).

$\mathrm{Bu}$ çalışmada görüşme tekniğinin tercih edilme sebebi, araştırma konusu ile ilgili derinlemesine bilgi edinebilmek istenmesi, görüşme yapılan kişilerin fikirleri doğrultusunda yeni fikirlerin ortaya çıkarılmak istenmesidir. Araştırmada, araştırmanın amacına uygun olduğu düşünülerek yüz-yüze, derinlemesine, yarı-yapılandırılmış görüşme yöntemi tercih edilmiştir. $\mathrm{Bu}$ yöntemin kullanılmasının sebebi, görüşme formunda bazı açık uçlu soruların bulunması ve demografik bilgilerin elde edilmek istenmesidir. Bu yöntemin tercih edilme sebebi, araştırılan konunun derinlemesine incelemeyi sağlamaktır. Alaçatı'nın markalaşma sürecinde festival turizminin rolü ile ilgili 8 katılımcı ile 7 açık uçlu soru çerçevesinde görüşme yapılmıştır. $\mathrm{Bu}$ çalışmada görüşme çeşitlerinden bireysel görüşme tekniği kullanılmıştır. Bunun nedeni, tek bir kişi üzerinde yoğunlaşabilmeyi sağlamasıdır. $\mathrm{Bu}$ sayede araştırma konusu hakkında görüşme yapılan kişinin düşünceleri ve görüşleri derinlemesine ele alınmıştır.

$\mathrm{Bu}$ çalışmada seçilen vakanın "Alaçatı Ot Festivali" olmasının nedeni, Ege bölgesinde en bilinen ve gözde beldelerinden olan Alaçatı'nın ev sahipliği yapmasıdır. Festivale katılan toplam turist sayısının ise 10 binlere ulaştığ belirtilmektedir. Araştırma evreni; araştırmacının ya doğrudan gözlemleyerek ya da ondan seçilmiş bir örnek küme üzerinde yapılan gözlemlerden yararlanarak hakkında görüş bildirebileceği evrendir (Karasar 2011:110). Araştırmada Alaçatı bölgesinde bulunan yerel esnaf, büyük ölçekli oteller, butik oteller, yiyecek-içecek işletmelerinin çalışanları ve festivalin yapımcısı olan Çeşme Belediyesi yetkilisi ile görüşülerek algıları belirlenmeye çalışılmıştır. Araştırma evrenini, Alaçatı bölgesi ve çevresinde olan işletmelerin çalışanları oluşturmaktadır. Görüşmeler, katılımcı ve yöneticilerin kendi çalışma ortamlarında yapılmıştır. Araştırmanın sadece Alaçatı bölgesinde yapılmayışının sebebi, Alaçatı Ot Festivali'nin her sene Alaçatı'nın kaldırabileceğinden çok fazla turist çekmesidir. Gelen turistlerin çevre bölgelere dağılması araştırmanın sadece Alaçatı bölgesindeki işletmelerle değil çevre bölgelerle de yapılması ihtiyacını doğurmuştur.

Örneklem, belli bir evrenden belli kurallara göre seçilmiş ve seçildiği evreni temsil yeterliliği kabul edilen küçük kümedir (Karasar 2011: 110). Bu araştırmada, Çeşme Alaçatı ve çevresindeki ticari işletmeleri kapsayan amaçlı örnekleme yöntemi kullanılmıştır. Araştırmanın verileri Aralık 2017 tarihlerinde gerçekleştirilen görüşme yöntemi ile elde edilmiştir. Yüz-yüze yapılan görüşmeler sonucunda Alaçatı Ot Festivali'nin yapımcısı olan Çeşme Belediyesi, Alaçatı ve çevresindeki işletmelerin yetkilileri dahil olmak üzere 8 kişiden oluşan örneklem büyüklüğüne ulaşılmıştır. Araştırma sonucunda elde edilecek sonuçları araştırmaya katılan işletmelerin yetkilileri ve çalışanlar ile yapılan görüşmeler sonucunda elde edilen veriler değerlendirilmiştir. Bununla birlikte, kullanılan görüssme formlarında katılımcıların görüş ve değerlendirilmelerinde objektif davrandıkları varsayılmıştır. Yüz-yüze görüşmeler 05/12/2017 ve 06/12/2017 tarihlerinde yapılmıştır. Her görüşme yaklaşık 40 dakika sürmüştür. Elde edilen veriler görüşme formu üzerinden yola çıkılarak katılımcıların görüşleri not alınıp kaydedilmiştir. Bu görüşmeler sonucunda 17 sayfa doküman elde edilmiştir. Yüz-yüze görüşülen katılımcıların dağılımı aşağıda belirtilmiştir:

- 5 Aralık 2017 tarihinde Çeşme BelediyesiKurumsal letişim ve Halkla lişkiler Müdürü ile görüşülmüştür (Festivali Belediye Organize ediyor.)

- 5 Aralık 2017 tarihinde Alaçatı'da bulunan yerel işletme sahibi ile görüşülmüştür (Alaçatı Hediyelik Eşya).

- 5 Aralık 2017 tarihinde Alaçatı Viento Butik Oteli'nin Müdürü ile görüşülmüştür.

- 6 Aralık 2017 tarihinde Alaçatı'da bulunan yiyecek-içecek işletmesi- Restoran-Bar Şefi ile görüşülmüsstür ( yi Resto Bar).

- 6 Aralık 2017 tarihinde 5 Yıldızlı Otel- Ön büro Sorumlusu (Şefi) ile görüşülmüştür. 
- 6 Aralık 2017 tarihinde 5 Yıldızlı Otel- SatışPazarlama Müdürü ile görüşülmüştür.

- 6 Aralık 2017 tarihinde 5 Yildızlı Otel- Kat Hizmetleri Müdürü ile görüşülmüştür.

- 6 Aralık 2017 tarihinde Alaçatı bölgesine hizmet veren gida üretim, dağıtım şirket sahibi ile görüşülmüş̧ür.

\section{Araştırmanın Güvenilirliği ve Geçerliliği}

$\mathrm{Bu}$ çalışma, kalitatif araştırmalarda güvenilirlik ve geçerlik sağlayan aşağıdaki ölçütlere uyularak gerçekleştirilmiştir (Berg, 2001: 57; Lincoln ve Guba, 1985: 328'dan aktaran (Deniz ve Bedir, 2017:181):

- Gizlilik: Katılımciların isim, unvan ve detaylı şahsi bilgileri talep edilmemiştir. Görüşmeler kapsamında elde edilen ses kayitları ve çözümlemeler araştırmacılar tarafından muhafaza edilmiş ve araştırma harici üçüncü şahıslarla paylaşılmamıştır.

- Güvenilirlik: Katılımcıların araştırmaya gönüllü katılımları sağlanmış ve tüm görüşme formları sayesinde güvenilirlik garanti altına alınmıştır. Görüşmeler katılımcıların yönlendirmelerine uyularak istenilen zaman ve mekânlarda gerçekleştirilmiş, yapılan yorumlar ve bulgular ve süreçle ilgili tüm bilgiler eş zamanlı olarak katılımcılara iletilmiştir. Böylelikle çalışmanın katılımcıların görüş, onay ve tecrübeleri dahilinde gerçekleşmiştir.

- Denetlenebilirlik: Çalışmanın denetlenebilirliği araştırmanın yöntem kısmında verilen detaylı ve adım adım bilgiler 1şı ğında gözden geçirilebilmektedir.

- Transfer edilebilirlik: Çalışmanın transfer edilebilirliği ve gelecek araştırmalara katkı sağlaması amacıyla ilgili diğer araştırmacılar için konuyla ilgili araştırmanın tüm süreci ve bilgileri yöntem kısmında detaylı bir biçimde ele alınmış ve aktarılmıştır (Deniz ve Bedir, 2017:181).

\section{Araştırmanın Bulguları ve Değerlendirilmesi}

Araştırmaya katılan bireyler, görüşme formunda bulunan yarı-yapılandırılmış ve açık uçlu sorulara görüşlerini ve deneyimlerini aktarmıştır. Görüşme formunun ilk kısmı demografik bilgilerin elde edilmesi amaçlanmıştır. Araştırmada katılımcıların demografik verilerini analiz etmek amaciyla frekans dağılımından faydalanılmıştır.
Katılımcıların demografik değişkenleri dört başlık altında incelenmiştir;

- Cinsiyet

- Yaş

- Eğitim Düzeyi

- Meslek

Bölgede çalışan katılımcılara ilişkin, \%25' lik orana denk gelen 2 kişilik kısmı kadın, \%75'lik kısma denk gelen 6 kişi ise erkektir. $\mathrm{Bu}$ oranlara bakıldığında, erkek katılımcıların kadın katılımcılara göre daha fazla olduğu tabloda görülebilir. Bölgede çalışan katılımcıların yaş aralığ 1 incelendiğinde, en fazla \% $75^{\prime}$ lik orana denk gelen 6 kişilik kısmı ile 35 yaş ve üstü yaş aralığıdır. 25-29 yaş aralığında ve 30-34 yaş aralığında olan katılımcılar \%12,5'lik kısma denk gelen 1'er kişi ile eşit orana sahiptir. Bu sonuçlara göre, araştırmaya katılan bireylerin 35 yaş ve üstü yaş grubu diğer yaş gruplarına oranla daha fazla olduğu tabloda da görülebilir.

Tablo 1: Araştırmaya Katılan Bireylerin Demografik Özelliklerine lişkin Bulgular

\begin{tabular}{|l|c|c|}
\hline $\begin{array}{l}\text { DEMOGRAF K } \\
\text { ÖZELL KLER }\end{array}$ & FREKANS & $\begin{array}{c}\text { ORAN } \\
\text { (\%) }\end{array}$ \\
\hline \multicolumn{2}{|c|}{ C NS YET (N=8) } \\
\hline Kadın & 2 & 25 \\
\hline Erkek & 6 & 75 \\
\hline \multicolumn{2}{|c|}{ YAŞ (N=8) } \\
\hline 25-29 arası EĞ T M DÜZEY (N=8) \\
\hline 30-34 arası & 1 & 12,5 \\
\hline 35 ve üstü & 1 & 12,5 \\
\hline \multicolumn{2}{|c|}{ MESLEK (N=8) } \\
\hline Ortaokul & 1 & 12,5 \\
\hline Lise & 5 & 62,5 \\
\hline Lisans & 7 & 12,5 \\
\hline Lisansüstü & 1 & 12,5 \\
\hline \multicolumn{2}{|c|}{ M̈zel sektörde çalışan } & 1 \\
\hline Kamu çalışanı
\end{tabular}

Bölgede çalışan katılımcıların eğitim seviyeleri incelendiğinde, ortaokul, lise ve lisansüstü eğitim katılımcıları \%12,5'lik orana denk gelen 1'er kişi ile aynı orana sahiptir. \%62,5' lik orana denk gelen 5 katılımcı ile lisans eğitimi gördüğü görülmektedir. $\mathrm{Bu}$ sonuçlara göre araştırmaya katılan bireylerin eğitim seviyesinin yüksek olduğu tabloda da görülmektedir. Bölgede çalışan katılımcıların, meslek yoğunluğuna bakıldığında $\% 12,5$ 'lik orana denk gelen 1 kişi kamu sektöründe, \%87,5'lik orana denk gelen 7 kişi özel 
sektörde çalışmaktadır. Bu sonuçlara göre, özel sektörde çalışan kişi sayısı kamu sektöründen daha fazla olduğu tabloda da görülmektedir.

Araştırmada uygulanan görüşme formunun ikinci kısmında katılımcılarla 7 soru sorulmuştur. Yapılan görüşmeler sonucunda, araştırma soruları çerçevesinde alınan yanıtların düzenlenmiş hali aşağıdaki gibidir.

\section{Alaçatı Ot Festivalinin düzenlenme sebebi sizce nedir?}

Yapılan görüssmeler sonucunda, katılımcılar Alaçat1 Ot Festivali'nin düzenlenme sebebini, Alaçatı'nın kültür birikimini, ülkeye ve dünyaya tanıtmak, Alaçatı doğasının zenginliğini, endemik otlarının çeşitliliğini tanıtmak ve bu otlarla pişirilen geleneksel yemeklerin kaybolmamasını sağlamak, turizme sezon başlamadan canlılık kazandırıp bölgeyi hareketlendirmek, bölge turizmini çeşitlendirmek ve süreklilik kazandırmanın yanında bölgesel ekonomik faaliyeti arttırma gibi nedenleri belirtmişlerdir.

2. Alaçatı Ot Festivalinin bölgeye gelen turist sayısının sizce arttırıcı bir özelliği var mıdır?

Araştırmaya katılan tüm bireylerin ortak düşüncesi bölgeye gelen turist sayısının artmasında Alaçatı Ot Festivali'nin rolünün büyük olduğudur. Festivalin, gelen turistlere tekrar gelme isteği uyandırdığı için sadece festival zamanı değil, diğer zamanlarda da gelmesini sağladığ 1 vurgulanmıştır. Festival turizminin destinasyonun turizm sezonunu uzatması ve mevsimlere yayması hedefini sağladı $\breve{g} 1$ belirtilmiştir.

3. Alaçatı'ya gelen turistlerin sizce gelme nedenleri nelerdir?

Araştırmaya katılan bireyler, Alaçatı'ya gelen turistlerin gelme nedenlerini, Alaçatı'nın mimari dokusu, bölgeyi keşfetmek istemeleri, Alaçatı Ot Festivali'ni deneyimlemek, Alaçatı'nın bir marka olması, özellikle yaz ayında sosyal hayatın hareketli olması ve bölgenin doğası olarak açıklamışlardır.

4. Alaçatı Ot Festivalinin işletmeler açısından önemini açıklar misınız?

Katılımcılar bu soruya, Alaçatı Ot Festivalinin işletmelerin yaz sezonu başlamadan bir prova olarak gördüğünü, festival büyük bir gelir sağladığı için işletmeler sezona başlamadan bu gelir sayesinde eksiklerini tamamladığını, sadece işletmelerin değil yerel halkında ev ekonomisine katkıda bulunduğunu ve Alaçatı Ot Festivali'nin işletmelere büyük bir müşteri potansiyeli sunduğu için işletmeler açısından oldukça önemli olduğu görüşü belirtilmiştir.

5. Alaçatı Ot Festivalinin destinasyon markalaşmasında etkisini bölge açısından nasıl de ğerlendiriyorsunuz?

Araştırmaya katılan bireylerin bazıları, Alaçatı denince akla hemen Alaçatı Ot Festivalinin geldiğini, festivalin ulusal ve uluslararası bölgenin tanınabilirliğini arttırdığını düşünmektedir. Bir kısım katılımcı ise, Alaçatı'nın zaten bir marka olduğunu ama Alaçatı Ot Festivali'nin, Alaçatı markasına katkı sağladığı düşünmektedir.

6. Festivalin bölgeye olan katkısını arttırmak için ne gibi önerilerde bulunabilirsiniz?

$\mathrm{Bu}$ soruda katılımcılar, Alaçatı Ot Festivalinin çok büyük bir potansiyele sahip olduğunu ve bunun kullanılması gerektiğgini belirtmiştir. $\mathrm{Bu}$ büyük potansiyele bölgedeki turizm çeşitlerinden bahsedilmesi gerektiğini düşünmektedir. Bununla beraber, festivalin bir haftaya yayılması, uluslararası nitelik kazanması, farklı yöresel gezi turlarının düzenlenmesi ve festivali genişletmek gibi önerilerde bulunmuştur.

\section{Festivalin ulusal ve uluslararası tanınabilirliğini} arttırmak için sizce neler yapılabilir?

Araştırmaya katılan bireyler bu soruya, sosyal medyanın daha çok kullanılması, gazete, dergi, radyo, televizyon gibi iletişim araçlarının kullanılması, stanbul, Ankara, zmir gibi büyük şehirlerde billboardlara reklam verilmesi ve turizm fuarlarında stant çalışması yapılması gerektiği cevabını vermiştir. Uluslararası anlamda ise, ülkelerin basın temsilcilerinin getirilebileceği, yurt dışı bağlantılı acenteler ile iş birliğine gidilmesi, uluslararası tanınmış sanatçıların getirilmesi, uluslararası medya için reklam bütçesi ve yurt dış1 fuarlarda tanitım, reklam yapmak gibi cevaplar verilmiştir.

Katılımcılardan ikisi farklı olarak; Alaçatı Ot Festivali olmadan önce de Alaçatı'nın popüler olduğunu düşünmesidir Alaçatı Ot Festivalinin bu kadar kalabalık olmasının sebebini Alaçatı'nın popüler olmasına bağlamıştır ve bu nedenle festivalin amacının dışına çıkmaya başladığını düşünmektedir. Özgünlük; Alaçatı Ot Festivali sayesinde yerel halk maddi manevi fayda sağlamasıdır. $\mathrm{Bu}$ sayede festivale gelen insanlarla 
yerel halkın ve işletmelerin pozitif bir ilişki içerisinde olmaktadır. Katılımcılar benzer olarak; Alaçat1 Ot Festivali'nin, bölgenin marka ve imajına katkı sağladığı, işletmelere yaz sezonu öncesi büyük gelir sağladı̆̆ı, festivalin bölgeye gelen turist sayısını arttırıcı bir özelliği olduğu, turizmin çeşitlendirilmesine katkı sağladığı ve turizm sezonunu uzatmada yararı olduğunu düşünmektedir.

\section{SONUÇ}

Festivallerin bölgeyi tanıtma, marka olmasında, ekonomik, sosyo-kültürel olarak etkilerini incelemek amacıyla Alaçatı ve çevresinde görüşülen bireylerden elde edilen veriler sayesinde, Alaçatı Ot Festivalinin gelen turist sayısını arttırıcı bir özelliği olduğunu, Alaçatı'ya gelen insanların bölgeyi ziyaret etme nedenlerinden biri festival olduğunu, festival zamanında işletmelerin büyük maddi kazanç sağladığ 1 ve bu sayede sezona girmeden eksiklerini tamamladıklarını, festivalin bölgede yaşayan insanların ev ekonomisine de katkı sağladığı sonucu çıkarılmıştır. Alaçatı denince birçok insanın aklına Ot Festivali geldiğini, ulusal ve uluslararası bölgenin tanınmasına yardımcı olduğu kanısına varılmıştır. Festivalin büyük bir potansiyele sahip olduğunu ve bu büyük potansiyelin bölgede yapılan diğer alternatif turizm çeşitlerinin ve etkinliklerin reklamı yapılarak bölgeye daha çok turist çekebileceği görüşüne varılmıştır.

Festivaldeki kalabalığın önlenmesi ve daha etkin bir festival olması için festivalin haftaya yayılması, festivalin çevresinin genişletilmesi, bölgedeki altyapının iyileştirilmesi, festival dönemi gezi turlarının düzenlenmesi, festivalin daha etkin bir biçimde olmasını sağlayacaktır. Festivalin tanınabilirliğini arttırmak için, sosyal medyanın daha aktif kullanılması, büyük şehirlerde billboardlara reklam verilmesi, ulusal ve uluslararası fuarlarda stant çalışması yapılması getirilebilecek önerilerdendir. Araştırma

sonucunda elde edilen bulgular 1şı̆̆ında, bir destinasyonda gerçekleştirilen festival ve etkinliklerin o destinasyonun tanıtımına, imajına ve marka olmasında olumlu yönde etkisi olduğunu, ekonomik ve sosyal olarak bölgedeki insanlara katkı sağladığı sonucuna varılmıştır.

\section{KAYNAKÇA}

Akpınar, M., (2013). Kuzeydoğu Anadolu Turizm Destinasyonu, Tanıtım Markalaştırma Araştırması.
Altındağ, M., (2005). Nitel Araştırma Teknikleri, (Yüksek Lisans Tezi). Ankara: Ankara Üniversitesi, Eğitim Bilimleri Enstitüsü, Eğitim Bilimleri Anabilim Dalı.

Berg, B. L. (2001), Qualitative Research Methods For Social Scientists, Fourth Edition, Allyn \& Bacon.

Bilgili, B., Yağmur, Ö. ve Yazarkan, H. (2012). Turistik Ürün Olarak Festivallerin Etkinlik ve Verimliliği Üzerine Bir Araştırma (Erzurum- Oltu

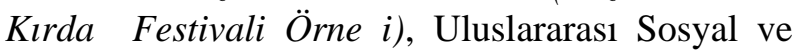
Ekonomik Bilimler Dergisi, 2/2, 117-124.

Chacko, H., ve Schaffer, J. (1993). The Evolution of Festival: Creole Christmas in New Orleans, Tourism Management, 14/6, 471-479.

Çelik, A., (2009). Destinasyon Pazarlama Unsuru Olarak Etkinlik Turizmi ve Etkileri: stanbul Örneği, (Yüksek Lisans Tezi). Ankara: Gazi Üniversitesi, Eğitim Bilimleri Enstitüsü, Turizm şletmeciliği Eğitimi.

Deniz, E. ve Demir, B. (2017) Hedonik Tüketim Kavramı Işı̆̆ında Gayrimenkul Sektöründe Pazarlama Stratejilerinin ncelenmesi: zmir Folkart Towers Örneği, Akademik Sosyal Araştırmalar Dergisi, 5(57), 170-191.

Deniz, E. ve Bedir, B. (2017) Havacılık Ulaşımında Niş Pazarlama Stratejilerinin Kullanılmast: Panjet (Pan Aviation) Örneği, Akademik Sosyal Araştırmalar Dergisi, 5(57), 170191.

DeRoche J.; DeRoche C., (2010), Encylopedia of Case Study Research, Vol. 1, Sage Publications, London.

Dimmock K. ve Tiyce M. (2001). Festivals and Events: Celebrating Special Interest Tourism, Special Interest Tourism, (Ed: N. Douglas ve R. Derrett), John Wiley and Sons, Milton, Queensland Australia.

Doğanl1, B., (2006). Turizmde Destinasyon Markalaşması ve Antalya Örneği, (Doktora Tezi). Isparta: Süleyman Demirel Üniversitesi, Sosyal Bilimler Enstitüsü, şletme Bölümü, şletme Anabilim Dalı.

Ekin, Y., (2011). Etkinlik Turizmi Kapsamında Festivaller ve Antalya Altın Portakal Film Festivali'nin Yerel Halk Üzerindeki Sosyal Etkileri Konulu Bir Araştırma, (Doktora Tezi). Antalya: Akdeniz Üniversitesi, Sosyal Bilimler Enstitüsü, Turizm şletmeciliği ve Otelcilik Anabilim Dalı. 
Falassi, A. (1987). Time Out of Time: Essay on the Festival, University of New Mexico Press, Albuquerque.

Getz, D. (1997). Event Management \& Event Tourism, Cognizant Communication Corporation, New York.

Getz, D. (2007). Event Studies, Theory, Research and Policy for Planned Events, First Edition, ISBN 10: 0-7506-6959-4.

Getz, D., (2008). Event Tourism: Definition, Evolution and Research, Tourism Management Vol.29, 3, 403-428.

Goldblatt, J. J. (1997). Special Events: Best Practice in Modern Event Management, Van Nostrand Reinhold, New York.

Karagöz, D., (2006). Etkinlik Turizmi ve Etkinlik Turizmi Bağlamında Yabancı Ziyaretçi Harcamalarının Ekonomiye Etkisi: Formula 1 2005 Türkiye Grand Prix Örneği, (Yüksek Lisans Tezi). Eskişehir: Anadolu Üniversitesi, Sosyal Bilimler Enstitüsü, Turizm Otel şletmeciliği Anabilim Dal1.

Karasar, N., (2011). Bilimsel Araştırma Yöntemi, Nobel Yayın Dağıtım, Ankara.

Kaya, F., (2014). Destinasyon Markalaşma Sürecinde Doğu Karadeniz Bölgesinin Doğal ve Kültürel Kaynakları Açısından Değerlendirilmesi, (Yüksek Lisans Tezi). stanbul: stanbul Üniversitesi, Sosyal Bilimler Enstitüsü, Turizm şletmeciliği Anabilim Dalı.

Keegan, Sheila F. (2009), Qualitative Research, Good Decision Making Through Understanding People, Cultures And Markets, Kogan Page Publishing.

Kömürcü, G. B., (2013). Etkinlik Turizmi Çeşidi Olarak Festivaller: Bozcaada Yerel Tatlar Festivali Örneği, (Yüksek Lisans Tezi) Çanakkale Onsekiz Mart Üniversitesi, Sosyal Bilimler Enstitüsü, Turizm şletmeciliği Anabilim Dalı.

Lincoln, Y. S.; Guba, E. G. (1985), Naturalistic Inquiry. Sage Publications, USA
Özdemir, G., (2007). Destinasyon Yönetimi ve Pazarlama Temelleri zmir çin Bir Destinasyon Model Önerisi, (Doktora Tezi) Dokuz Eylül Üniversitesi, Sosyal Bilimler Enstitüsü, Turizm şletmeciliği Anabilim Dalı.

Özden, M. Y. ve Durdu, L., (2016). Ĕgitimde Üretim Tabanlı Çalışmalar çin Nitel Araştırma Yöntemleri, Anı Yayıncılık, Ankara, ISBN: 978605-170-109-7.

Özkul E. ve Demirer D., (2012). Şehirlerin Turistik Markalaşmasında Kalkınma Ajanslarının Rolü, Bölge Planları Üzerine Bir Doküman ncelenmesi, şletme Araştırmaları Dergisi, 157-181.

Pekyaman. A., (2008). Turistik Satın Alma Davranışında Destinasyon majının Rolü Afyonkarahisar Bölgesinde Bir Araştırma (Doktora Tezi). Afyon: Afyon Kocatepe Üniversitesi, Sosyal Bilimler Enstitüsü, şletme Anabilim Dalı.

Ritchie, J.; Lewis, J. (2003), Qualitative Research Practice, A Guide For Social Science Students and Researchers, London, Sage Publications.

Seggie, F. N. ve Bayyurt Y., (2015). Nitel Araştırma Yöntem, Teknik, Analiz ve Yaklaşımları, Anı Yayıncılık, Ankara, ISBN: 978-605-170-028-1

Şengül, S., Genç, K., (2016). Festival Turizmi Kapsamında Yöresel Mutfak Kültürünün Destekleyici Ürün Olarak Kullanılması: Mudurnu pekyolu Kültür Sanat ve Turizm Festivali Örneği, Pamukkale Üniversitesi Sosyal Bilimler Enstitüsü Dergisi Sayı 23, s.79-89.

Yıldırım, H., (2017). Etkinlik Turizmi 'Destinasyon Seçim Sürecinde Etkinlikler', Detay Yayıncılık, Ankara, ISBN: 978-605-9440-53-0.

http://www.narsanat.com/ulkemizde1300-festivaloldugunu-biliyor-muydunuz/ Erişim Tarihi: 19 Ekim 2017 (Aktif).

Yin, Robert K. (2002), Case Study Research (Design and Methods), California: Sage Publication. 